\title{
Comparative study on cold chain logistics distribution of agricultural products between China and other countries
}

\author{
Yang $\mathrm{Yu}{ }^{\mathrm{a}}$, Hongsheng Sun ${ }^{\mathrm{b}}$, Xifu Wang ${ }^{\mathrm{c}}$ \\ School of transportation, Beijing jiaotong University, Beijng 100044, China \\ a759894710@qq.com, bhshsun@bjtu.edu.cn, cxfwang1@bjtu.edu.cn
}

Keywords: Agricultural, Products Logistics, Cold Chain Distribution, Index System.

\begin{abstract}
With the development of people's living standards and fresh food E-commerce, cold chain logistics of agricultural products as an important part of food safety chain will enjoy more and more attention. But in China the cold chain distribution industry of agricultural products started relatively late, there are still market chaotic, uneven service quality level, extensive management, and other issues. This paper based on extensive literature review and the actual development, to introduce and analyzes the industry present condition of China and foreign country; to compare on several measures of policy environment, logistics facilities and the market situation; using the fuzzy comprehensive evaluation method based on Analytic Hierarchy Process, choosing Japan as a representative of the developed countries, to make analysis between Chinese and foreign cold chain distribution situation of agricultural products; on the basis of experience from abroad, to make recommendations of China's agricultural cold chain logistics development.
\end{abstract}

\section{Introduction}

Because of the needs of China's exports of fresh food processing trade, China's agricultural products cold chain logistics occurred in the late 1950s, mainly in the field of foreign trade of meat. In 1982, the government promulgated the "Food Sanitation Law", which effectively promoted the development of agricultural products cold chain logistics industry. With the rapid development of China's cold chain logistics, China has formed a part of the agricultural products processing industry, which is reflecting the regional differences between China and foreign countries in agricultural products cold chain logistics system. In recent years, with the popularity of the Internet and information technology applications, as well as the development of fresh electricity supplier, the cold chain logistics technology developed quickly. Cold chain logistics distribution of agricultural products is the last part of the circulation of agricultural products. After the agricultural products from the production getting through pre cooling, low temperature storage, cold chain transportation and other links, consumers receive the products finally (Figure 1).

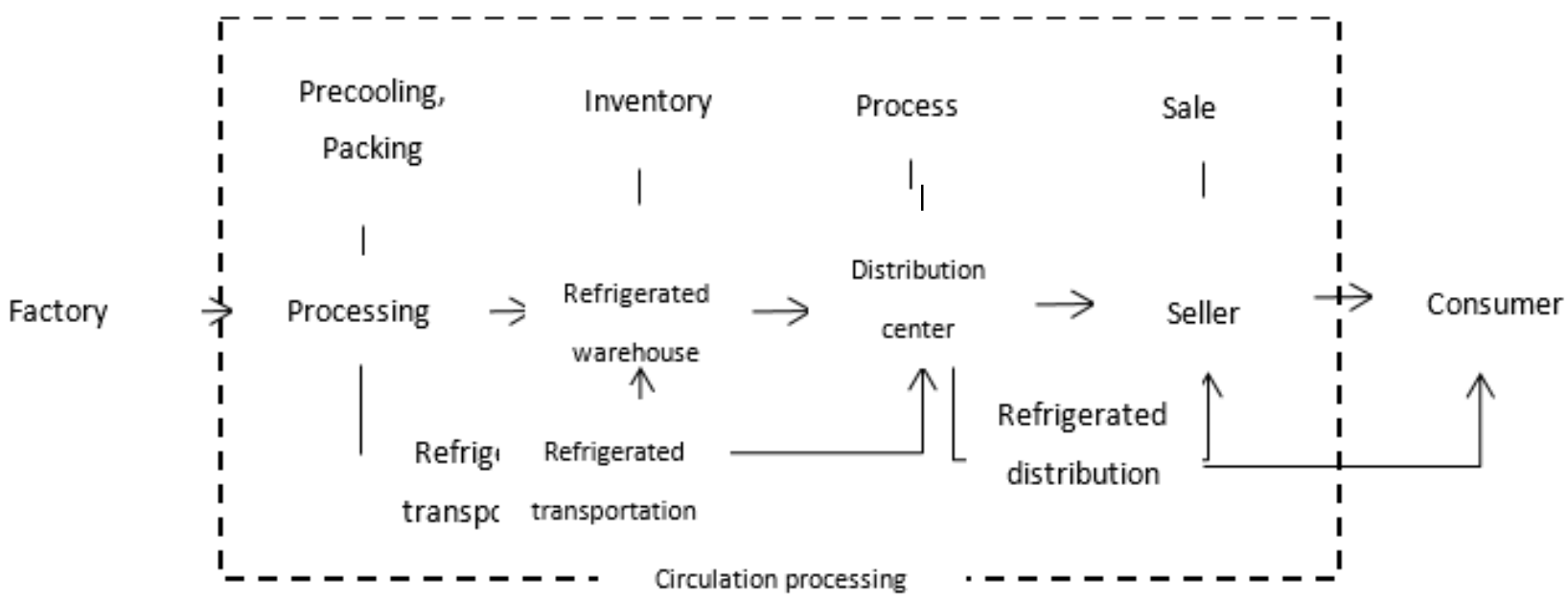

Fig.1 Circulation mode of agricultural products cold chain logistics 
At present, many countries in the world have developed a lot of agricultural products logistics systems. Japan, as a representative country of agriculture economy in Asia, has dense population and small peasant economy, which are very similar to China so the learning experience of Japan in agricultural products cold chain logistics has a high reference value for our country. At present, Japan has established a more developed agricultural products cold chain distribution system, more than $80 \%$ of the total output of crops are traded in the wholesale market, the loss rate of agricultural products is only about $3 \%$.

The United States is one of the most developed countries for agricultural production and trade, the production of agricultural products in the world. The output of America accounted for about $20 \%$ of the world total output of agricultural products, driving the improvement and development of the agricultural products distribution. The United States has become one of the world's advanced agricultural products cold chain logistics distribution in the first country. The United States established a modern vegetable cold chain logistics system called "from farm to table", the system includes pre cooling, cold chain logistics, transportation, refrigerated Wholesaling, supermarket refrigerator, consumer refrigerator etc., and the weight loss accounted for only $1 \%$ to $2 \%$ of the total weight.

\section{Discussion}

Comparing of the distribution situation of cold chain logistics of agricultural products at home and abroad, the developed countries in cold chain logistics industry started earlier, which has made a developed transportation network, advanced cold chain logistics facilities and advanced information technology to develop more perfect laws and regulations and industry standards. Compared with the domestic, agricultural products logistics, developed countries have obvious advantages in the aspects of cold storage capacity, refrigeration efficiency, and the loss rate of agricultural products. The comparison between them is shown in table 1 .

Table 1. Comparison of logistics development between China and foreign countries

\begin{tabular}{|c|c|c|}
\hline & China & Developed countries \\
\hline $\begin{array}{c}\text { Fruit and } \\
\text { vegetable loss } \\
\text { after harvest }\end{array}$ & $25 \% \sim 30 \%$ & $5 \%$ \\
\hline $\begin{array}{l}\text { Refrigerating } \\
\text { capacity }\end{array}$ & 8 Million tons & World total 80 million tons \\
\hline $\begin{array}{l}\text { Refrigerated } \\
\text { transport rate }\end{array}$ & $10 \% \sim 20 \%$ & America $80 \% \sim 90 \%$, Japan $98 \%$ \\
\hline $\begin{array}{c}\text { Cold chain } \\
\text { logistics system }\end{array}$ & $\begin{array}{l}\text { China has not yet formed a perfect cold } \\
\text { chain logistics system. Supply chains } \\
\text { often get broken and the efficiency is } \\
\text { low. The most important thing is that } \\
\text { cold storage technology is not widely } \\
\text { used in china. }\end{array}$ & $\begin{array}{l}\text { Developed countries in Europe and } \\
\text { the United States have established a } \\
\text { variety of efficient refrigeration } \\
\text { systems, which insure products to } \\
\text { be perfectly transported }\end{array}$ \\
\hline
\end{tabular}

In order to compare the situation of agricultural products cold chain logistics in China and foreign countries, it is necessary to establish a reasonable index evaluation system. According to the summary of the domestic and foreign agricultural products cold chain logistics distribution and the relevant literature theory, this paper has set up 3 first level indicators, 6 second level indicators and the 19 third level indicators (Table 2). 
Table 2. Agricultural products cold chain logistics distribution index system

\begin{tabular}{|c|c|c|c|}
\hline \multirow{20}{*}{$\begin{array}{c}\text { Index } \\
\text { system }\end{array}$} & First index & Second index & Third index \\
\hline & \multirow{5}{*}{ Distribution environment } & \multirow{2}{*}{$\begin{array}{l}\text { Institutional } \\
\text { environment }\end{array}$} & Policy and law environment \\
\hline & & & Logistics standard \\
\hline & & \multirow{3}{*}{ Technological environment } & $\begin{array}{c}\text { Information technology } \\
\text { penetration }\end{array}$ \\
\hline & & & $\begin{array}{c}\text { Cold chain technology } \\
\text { penetration }\end{array}$ \\
\hline & & & $\begin{array}{l}\text { Retrospective technology } \\
\text { penetration }\end{array}$ \\
\hline & \multirow{5}{*}{$\begin{array}{l}\text { Distribution } \\
\text { facilities }\end{array}$} & \multirow{3}{*}{ Hardware facilities } & Refrigerated truck scale \\
\hline & & & Cold storage ratio \\
\hline & & & Machine utilization \\
\hline & & \multirow{2}{*}{ Software facilities } & $\begin{array}{c}\text { Information system application } \\
\text { rate }\end{array}$ \\
\hline & & & Professional ratio \\
\hline & \multirow{9}{*}{$\begin{array}{l}\text { Distribution } \\
\text { operation }\end{array}$} & \multirow{3}{*}{ Operation efficiency } & Vehicle load rate \\
\hline & & & Cold storage turnover days \\
\hline & & & Average number of handling \\
\hline & & \multirow{6}{*}{ Operation effect } & Logistics activity cost \\
\hline & & & On-time Delivery \\
\hline & & & Distribution loss rate \\
\hline & & & Problem rate \\
\hline & & & Customer satisfaction \\
\hline & & & Order fulfillment rate \\
\hline
\end{tabular}

\section{Summary}

All in all, China needs to make some measures to improve China's agricultural products cold chain logistics as following.

Firstly, we should strengthen agricultural products cold chain distribution infrastructure, information technology and personnel development. Throughout the development process of agricultural products cold chain distribution in developed countries, the overall supply of cold chain logistics is the premise and foundation to ensure the smooth operation of cold chain distribution. First of all, it is reasonable to plan and construct cold chain logistics infrastructure, increase the investment in infrastructure. According to different requirements for temperature and humidity, agricultural products cold chain should be equipped with transport and warehousing of cold chain equipment, and improve the utilization rate of equipment in order to reduce the operation cost of cold chain logistics system. Second, to strengthen the informatization construction in the cold chain distribution in the process of the establishment of agricultural products cold chain logistics information system platform, to achieve inter enterprise information and resource sharing, and continuous innovation of cold chain logistics technology and extensive application of RFID and GIS and other logistics information technology, dynamic monitoring continuously and effectively for each link of the cold chain distribution, transportation and inventory tracking the position of the food and the state, to ensure quality and safety of agricultural products in the transportation process, improve the management level of cold chain logistics. Third, we should strengthen the construction of cold chain logistics personnel and training, including logistics and technical personnel, logistics management personnel and business planning staff. More importantly, to strengthen the cold chain distribution personnel skills is considerable. 
Secondly, we need to improve the degree of cold chain logistics market and develop the third party cold chain logistics. At present, in the cold chain logistics market, the third party cold chain logistics distribution has gradually become the main body of market competition. China cold chain logistics enterprises should learn from the advanced experience of developed countries, continue to expand the scope of business according to the market demand, improve the level of cold chain distribution enterprises, pay attention to cold chain logistics distribution of value-added services, provide professional and personalized service, and constantly improve the degree of marketization of agricultural products cold chain logistics.

Last but not least, it is necessary for the government to strengthen guidance and support and improve the legal system and industry standards. In the regulations, the Chinese government should agricultural products cold chain logistics as soon as possible to formulate standard system of improve policies and regulations of agricultural products cold chain logistics market, to make the implementation of dynamic monitoring information system and data based on feedback, to promote the further development of the industry and so on. Secondly, in support of government policy, government departments should strengthen the cold chain distribution industry support policies, land, taxation, financial approval from low interest loans and other aspects of support, building a good policy environment and promoting the gradual development of the cold chain logistics distribution.

\section{References}

[1]. Stanisław Iwan, Kinga Kijewska, Justyna Lemke. Analysis of parcel lockers' efficiency as the last mile delivery solution-the results of the research in Poland [J]. Transportation Research Procedia, 2016(12):644-655.

[2]. Cameron Hazel M.G.Trends in Agrieultureand Agribusiness: Knoeledge is Power [J]. Joumal of Business \& Finanee Librarianship. 2006,(12):3-32

[3]. Hendrikse G.W.,J.Bijman. Ownership Strueture in Agri-food Chanis: The Marketing Coo Perative [J]. Ameriean Journal of Agrieultural Economics. 2002,(84):104-119 